\title{
Evaluation of Infraorbital Canal Anatomy and Related Anatomical Structures With Multi-Detector Ct
}

\author{
Infraorbital Kanal Anatomisi ve Kanal ile İlișkili Anatomik Yapıların Çok-Dedektörlü BT ile Değerlendirilmesi
}

Çağlar Uzun'1, Șaziye Eser Șanverdi², Evren Üstüner¹, Mehmet Ali Gürses², Șafak Șalvarlı²

Ankara University School of Medicine, Department of Radiology Integra Medical Imaging Center, Ankara, Turkey

* Bu çalışma poster olarak 2013 Avrupa Radyoloji Kongresi'nde

sunulmustur (doi.org/10.1594/ecr2013/C-2407)
Received : April 04,2016• Accepted: April 28, 2016

Corresponding Author

Çağlar Uzun, MD,

E-mail:cuzun77@yahoo.com

Phone: 5082260

Fax: 3100808

Ankara University School of Medicine, Department of Radiology Ibni Sina Hospital, Sinhiye, 06100 Ankara, TURKEY

Aims: The purpose of this study is to assess the anatomic features and variations of the infraorbital canal (IOC).

Material and method: Digitally archived paranasal sinus computed tomography (CT) images of 492 IOC of 46 adult patients (mean age; $36.7 \pm 24.4$ year, M/F: 154/92) were retrospectively reviewed. Course and bony structure of the IOC, existence of anterior superior alveolar canal (ASAC) and number of the infraorbital foramen (IOF) were evaluated.

Results: IOC was observed as a groove, without a superior wall, rather than a canal in the majority of the images (64\%). Presence of a true canal was observed in the $23 \%$ of the images. $10 \mathrm{C}$ coursed along the superior - lateral wall of the adjacent maxillary sinus in $83 \%$ of images $(n=408)$. IOF was single in $88 \%$ of images $(n=433)$. ASAC was detected in $44 \%$ of the images $(n=216)$. In comparison to IOC, ASAC had a lateral $(n=$ $135,62.5 \%$ ) or inferior $(n=81,37.5 \%)$ course. In the $72.6 \%$ of the patients presenting with ASAC, conjunction with IOC was detected just before the IOF.

Conclusion: Anatomic features of $\mathrm{IOC}$ should be demonstrated in the patients who need orbital, maxillary sinus or dental implant surgery to prevent iatrogenic trauma to neurovascular bundles within. CT can provide accurate data in the evaluation of IOC anatomy, and correlative anatomical studies would strengthen the imaging.

Key Words: Infraorbital Canal, Anterior Superior Alveolar Canal, Inferior Alveolar Nerve, Multi-Detector Computed Tomography

Amaç: Bu çalıșmanın amacı infraorbital kanalın (IOK) anatomik özellikleri ve varyasyonlarının değerlendirilmesidir.

Gereç ve Yöntem: Dijital olarak arșivlenmiș 246 olguya ait (ortalama yaș; $36.7 \pm 24.4$, E/K: 154/92) 492 iOK'nın bilgisayarlı tomografi (BT) görüntüleri retrospektif olarak gözden geçirilmiștir. IOK'nın seyri ve kemik yapısı, anterior superior alveolar kanal (ASAK) varlığı ve infraorbital foramen (IOF) sayısı değerlendirilmiștir.

Bulgular: IOK incelemelerin çoğunda (\%64) kanaldan çok oluk olarak görüntülenmiștir. Görüntülerin \%23'ünde gerçek bir kanal görülmüștür. IOK, görüntülerin \%83'ünde $(n=408)$ komșu maksiller sinüsün süperior-lateral duvarı boyunca seyretmiștir. Görüntülerin \%88'inde $(n=433)$ tek iOF izlenmiștir. ASAK görüntülerin \%44'ünde $(n=216)$ mevcuttur. ASAK, IOK'nın lateralinde $(n=135, \% 62.5)$ ya da inferiorunda ( $n$ $=81, \% 37.5$ ) görülmüștür. ASAK'ın görüldüğü olguların \%72.6'sında ASAK ve IOK, IOF'nin hemen öncesinde birleșme göstermektedir.

Sonuç: İçerisindeki nörovasküler yapıların iyatrojenik travmalardan korunması amacıyla orbital, maksiller ve dental cerrahi öncesi IOK'nın anatomik özelliklerinin ortaya konması gereklidir. IOK anatomisinin değerlendirilmesinde BT doğru bilgi sağlayabilmektedir. Görüntüleme bulgularının anatomik çalıșmalar ile korelasyonu görüntülemenin değerini arttırabilir.

Anahtar Sözcükler: Infraorbital Kanal, Anterior Süperior Alveoler Kanal, Inferior Alveoler Sinir, ÇokDedektörlü Bilgisayarlı Tomografi

Infraorbital canal (IOC) is a bony canal that is located in the superior - lateral wall of the maxillary sinus. IOC is continuous with the inferior orbital fissure and anteriorly opens into the infraorbital foramen (IOF) (Fig 1) (1). IOC contains important anatomic structures such as inferior orbital nerve (ION) and inferior orbital artery (IOA). ION is a branch of the maxillary nerve, which completely consists of sensorineural fibers, and innervates the ipsilateral mid-face. ION has afferent fibers from the skin and the conjunctiva of the ipsilateral lower eyelid; the skin and the mucosa of the nose; skin and buccal epithelium of the upper lip, the upper teeth and related gingivae (1-3). 
With the posterior - superior alveolar artery (PSAA), IOA is the most important artery that supplies the maxillary bone (4). The rich intraosseous arterial anastomosis of IOA and PSAA branches supply the maxillary sinus mucosa, bony constituents and the buccal epithelium $(4,5)$.

Within IOC, ION provides three distinct branches: middle - superior alveolar nerve, posterior -superior alveolar nerve, and anterior - superior alveolar nerve (G). Anterior - superior alveolar nerve (ASAN) branches from the ION at the level of the $1 / 3$ anterior portion of the IOC and runs within a tiny canal, named as anterior - superior alveolar canal (ASAC) by Song et al. (7). ASAC might join into IOC just before the opening of IOF, or may have a separate foramen (Fig 2).

IOC, the canal that encases important neurovascular structures, is an area of interest in patients with intractable or pharmacologically unresponsive trigeminal neuralgia for nerve block therapy purposes (8). In addition, ION and IOA might come under iatrogenic trauma during maxillofacial, orbital and dental surgery. To avoid iatrogenic injury, anatomic course of IOC and the topographic features of IOF should be known in patients requiring mid-facial and orbital surgery $(9,10)$. Therefore, preoperative assessment with multi-detector computed tomography (CT) of both IOC and IOF may help treatment planning and surgical management.

In this study, we aimed to investigate the anatomy of IOC and related structures with multi-detector CT in the adult population.

\section{Material and methods}

A total of 492 IOC images of 246 adult patients who had been examined with paranasal sinus CT for various medical reasons were reviewed from our institutions digital picture archiving database (PACS). Mean age was 36.7 \pm 24.4 years with a range of $19.6-$ 56.3 years. Male to female ratio was $154 / 92$.
Imaging was done with a 16 detector CT scan (Siemens, Erlangen, Germany). Imaging frame was marked from the roof of the frontal sinuses to the bottom of the maxillary sinuses with a $12 \times 12 \mathrm{~cm}$ of field of view. The images were obtained with $3 \mathrm{~mm}$ slice thickness, 16 x $1 \mathrm{~mm}$ collimation, $200 \mathrm{mAs}$, and $120 \mathrm{kVp}$. Then, thin slice reconstructions with a thickness of $0.75 \mathrm{~mm}$ were made. Subsequently, sagittal - oblique reformatted images parallel to the course of IOC were obtained from these thin reconstructions.

Analysis was done by a radiologist experienced in head and neck imaging (SES). The course and bony structure of the IOC were evaluated using the sagittal - oblique reformatted images.

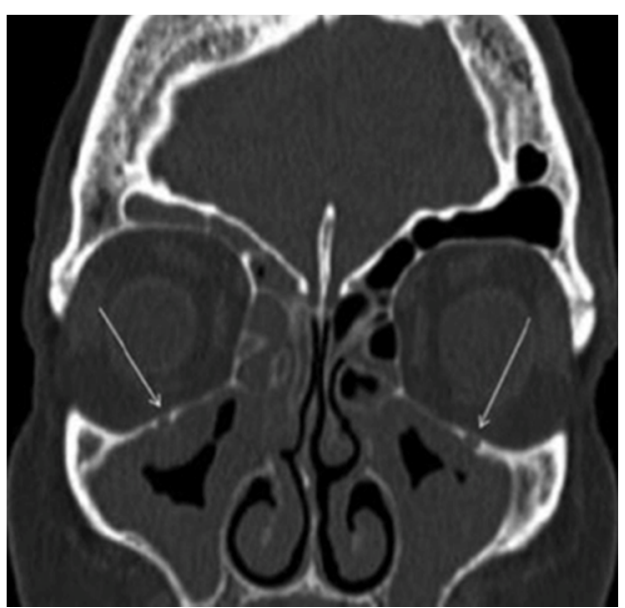

Figure 1a
Number of IOF, the existence and the course of ASAC were mainly reviewed using axial images. Coronal and sagittal reformatted images were referred in case of need.

Bony structure of IOC was classified using the criteria employed by a previously reported study (7). According to the developmental features of bony walls, IOC was classified as a true canal (definite bony walls without any defect), a canal with patchy superior wall (superior wall consisted of bony islets, but complete bony walls in rest of the canal), as a groove (absence of superior wall). The course of IOC was categorized according to its location; whether the canal is completely located in the superior lateral wall of the maxillary sinus or

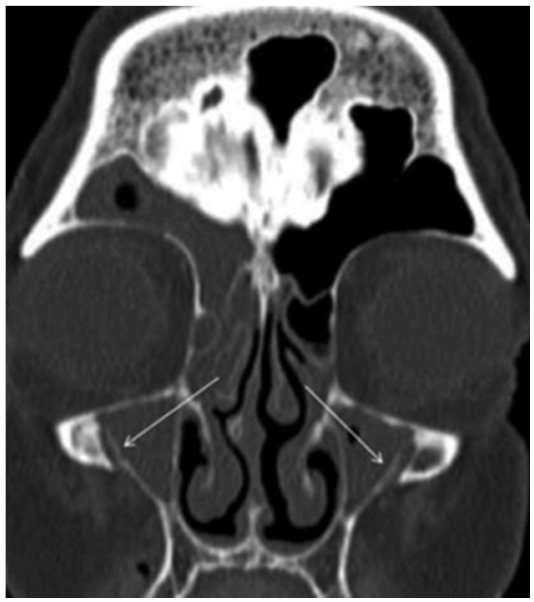

Figure 1b

Figure 1: Coronal reformatted CT images; inferior orbital canals (arrows) are bilaterally seen in the floor of the orbit (a) and in the lateral wall of the maxillary sinuses (b).

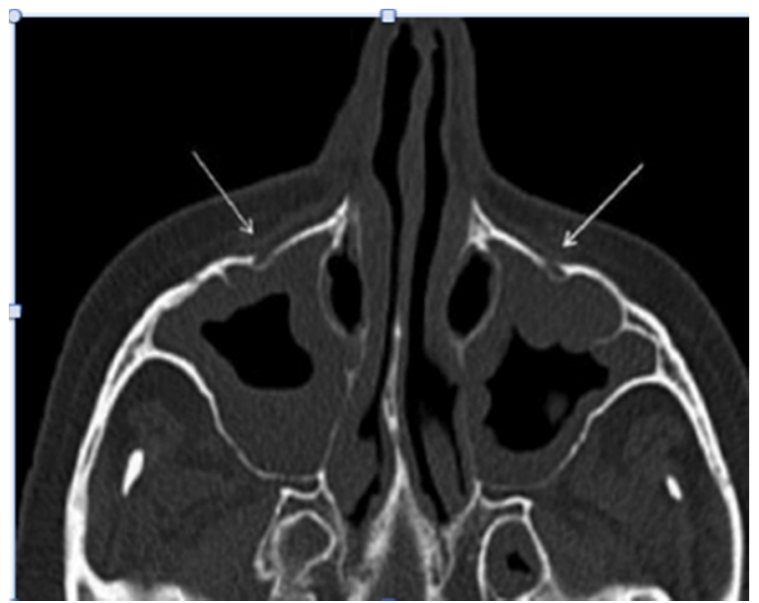

Figure 2: Infraorbital foramina (arrows) are seen in the axial CT image. 
partially located in the lateral wall and partially located in the cavity of the maxillary sinus. The relation of ASAC and IOC such as conjunction points, opening features of the canals whether separately or together, and number of IOF were also evaluated. Age and gender differentiations were analyzed.

Patients with maxillofacial trauma and abnormality, and the examinations with motion artifacts were not included in the study.

Local ethical committee approval was obtained for this study.

Statistical analyses were made by SPSS 15.0 version for Windows (SPSS, Chicago, Ill). Descriptive statistics were used for general distribution according to age and gender. One way analysis (ANOVA) was used to obtain the differences between two genders. Fisher's Exact test was performed to analyze the relation between the age and features of IOC and IOF. Threshold for the statistical analyses was set as $\mathrm{P}<0.05$.

\section{Results}

IOC was observed as a groove, without a superior wall, rather than a canal in the majority of the images $(n=315$, $64 \%)$. In $23 \%$ of the images $(n=113)$ a deficient bony roof was detected (Fig 3). True canal was only noted in the $13 \%$ of the images $(n=64)$ (Table 1).

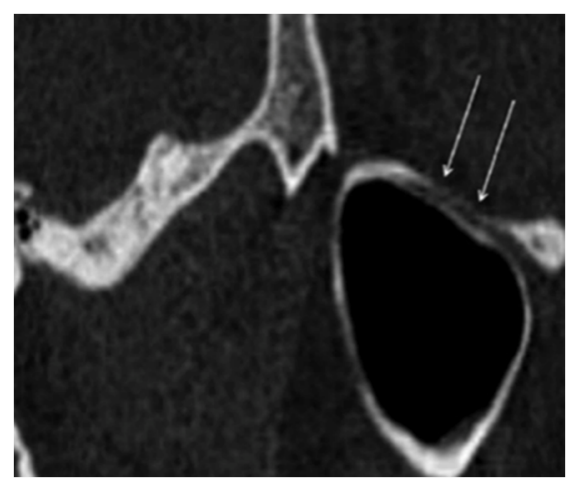

Figure 3: Sagittal - oblique reformatted CT image, infraorbital canal (arrows) is seen with patchy osseous appearance of the superior wall of maxillary sinus.
Table 1: Bony structure of the IOC

\begin{tabular}{|l|l|}
\hline IOC & $\begin{array}{l}\text { Number and } \\
\text { percentage of } \\
\text { images }\end{array}$ \\
\hline True bony canal & $64(13 \%)$ \\
\hline Patchy superior wall & $113(23 \%)$ \\
\hline Groove & $315(64 \%)$ \\
\hline
\end{tabular}

IOC coursed through the superior lateral wall of the adjacent maxillary sinus in $83 \%$ of the images $(n=408)$. In the $17 \%$ of images $(n=84), 1 / 3$ anterior portion of IOC was within the sinus cavity, while $2 / 3$ posterior portion was coursing in the maxillary sinus wall. Neither bony structure, nor course of IOC revealed any significant correlation with age or gender ( $\mathrm{P}>1$, for each pair).

In this study, ASAC was identified as a distinct canal in the 216 of the images (44\%). According to the localization of IOC, ASAC revealed two different courses; lateral $(\mathrm{n}=135,62.5 \%)$ and inferior $(\mathrm{n}=81,37.5 \%)($ Fig 4$)$ (Table 2).

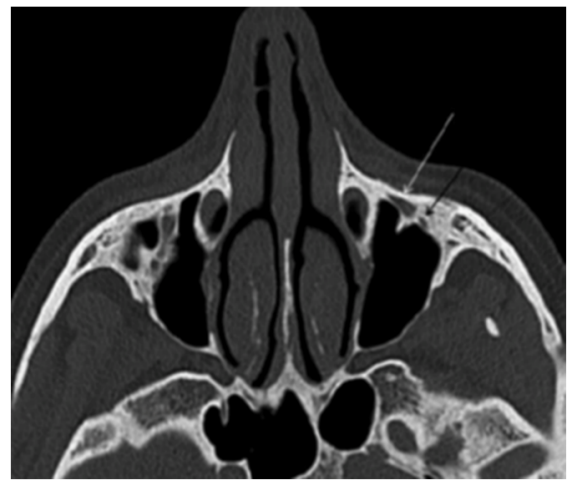

Figure $4 a$

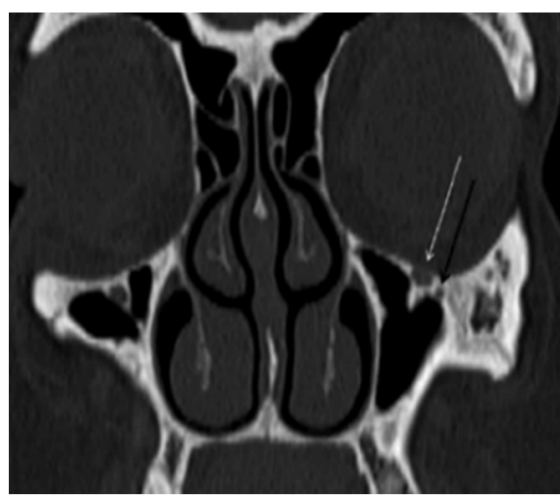

Figure $4 b$

Figure 4: Inferior orbital canal (white arrow) and anterior-superior alveolar canal (black arrow) are seen in the axial (a) and in the coronal reformatted (b) CT image
Table 2: Course of ASAC

\begin{tabular}{|l|l|}
\hline ASAC & $\begin{array}{l}\text { Number and percentage of } \\
\text { images }\end{array}$ \\
\hline $\begin{array}{l}\text { Course } \\
\text { (according } \\
\text { to IOC) }\end{array}$ & Lateral, $\mathrm{n}=135(62.5 \%)$ \\
\cline { 2 - 2 } & Inferior, $\mathrm{n}=81(37.5 \%)$ \\
\hline
\end{tabular}

ASAC: anterior - superior alveolar canal,

IOC: inferior orbital canal

IOF was single in $88 \%$ of the images ( $n$ $=433$ ). Double IOF was detected in $59(12 \%)$ images, one belonging to IOC and the other to ASAC (Table $3)$. In the group of the patients with ASAC, conjunction with IOC just before IOF was noted $(n=157,72.6 \%)$.

Neither course, nor existence of ASAC revealed any significant correlation with age or gender $(\mathrm{P}>1$, for each pair). No statistical correlation was found between the number of IOF and age or gender, either $(\mathrm{P}>1$, for each pair).

Table 3: Number of IOF

\begin{tabular}{|l|l|}
\hline IOF & $\begin{array}{l}\text { Number and percen- } \\
\text { tage of images }\end{array}$ \\
\hline Double & $59(12 \%)$ \\
\hline Single & $433(88 \%)$ \\
\hline
\end{tabular}

IOF: Infraorbital foramen

\section{Discussion}

Mid-face is the cornerstone for plastic and aesthetic interventions, dental implantation, maxillary sinus exploration and orbital procedures. Relatively thin skin and subcutaneous fat tissue in comparison to other body parts provide easy access to important vascular structures and neural plexuses in that area. Intense neurovascular supply of mid-face tends that area vulnerable to iatrogenic trauma. IOF, the opening of ION and IOA and the anatomical structure that is most superficially located in mid-face have been studied in many previous studies (11-13). In this study we mainly analyzed the association of foramina of IOC and ASAC in regard to their courses.

In the 3 dimensional CT study that has been reported by Lee et al. (12) The course and the shape of the IOC, and the anatomical landmarks adjacent to IOF were analyzed. In the study of Hindy and Abdel-Raouf (11), which 
had been conducted on dry skulls, the course of IOC, and the distance from the center of IOF to the lateral nasal border and to the inferior border of the orbit were evaluated. According to the evaluation parameters, except the distances between IOF and related anatomical structures, our study is quite close to the study by Hindy and Abdel-Raouf.

We analyzed the bony texture of IOC in regard to the authors' classification mentioned above; and we found true bony canal in $13 \%$, a patchy superior wall in $23 \%$, and a groove configuration in $64 \%$ of CT images. IOC was classified in the study of Hindy and Abdel-Raouf (11) as true canal in 25\%, patchy wall in $15 \%$, and a groove in $60 \%$ Frequency of true bony canal was lower in our study in comparison to the study of Hindy and Abdel-Raouf. We suggest that the higher resolution provided by the multi-detector CT technology in our study might have led to the detailed evaluation of the superior wall of the IOC.

We also evaluated the course of IOC within the maxillary sinus. In 408 of the images $(83 \%)$, IOC coursed in the superior - lateral wall of the maxillary sinus. In the remaining 84 images $(17 \%)$, IOC coursed in the superior - lateral wall of the maxillary sinus posteriorly, and in the maxillary sinus cavity anteriorly. In the latter group, approximately $2 / 3$ of IOC was encountered by the maxillary sinus wall whereas $1 / 3$ anterior portion showed free course in the sinus cavity. In 74 patients, one IOC revealed intra-osseous course and the other revealed partially intra-osseous and partially intra-sinus course. According to the best of our knowledge, there is no study in the English literature that has investigated the course of IOC within the maxillary sinus. In the light of statistical analyses we thought that variations in the course of the IOC might be associated with the pneumatization features of the maxillary sinus. However, involvement of other possible factors such as genetic and environmental factors cannot be ruled out.

We found a distinct ASAC in the 216 of the images (44\%). According to the localization of the IOC, ASAC revealed two different courses as laterally $(\mathrm{n}=135,62.5 \%)$ and inferiorly ( $\mathrm{n}$ $=81,37.5 \%$ ). Song et al (7). have also reported that lateral course of ASAC according to IOC was more frequent. In their cadaveric study lateral course of ASAC was reported as $57.5 \%$ and inferior course as $37.5 \%$. They have stated medial course of ASAC in 2 patients in their series. But they have also declared that medially coursed ASAC finally joined to the IOC. In the micro-computed tomography study of cadavers by Song et al. the number and the association of ASAC and IOC were analyzed. They reported multiple ASACs in some cases. They have also stated that ASACs frequently aroused from the 1/5-1/2 anterior portion of IOC with an angle of 37 degree (7). In this study we did not find multiple ASACs. Moreover we identified ASAC in some of the images, not in all sinuses. Findings showed that ASAC evaluation carried out with CT scanners provide higher resolution.

In this study single IOF was found in 433 of the images $(88 \%)$. In the remaining images $(\mathrm{n}=59,12 \%)$ double IOF with two distinct foramina one belonging to IOC and the other to ASAC was observed. In the English literature the prevalence of double IOF has been reported as $2.2 \%$ to $18.2 \%$ (11-12, 14-19). Hindy and Abdel-Raouf (11) have found double IOF in the $10 \%$ of their study population that consisted of Egyptians. Boopathi et al (15). have reported accessory IOF in 13 of the 80 samples
$(16.25 \%)$ in their anthropometric human skull study in a distinct ethnic group, South Indians. In the study of Bressan et al (16). anatomical features of IOF have been analyzed in 1064 human skulls, and accessory IOF rate have been reported as $4.7 \%$. They have stated a slight male dominancy (5.4\% in male and $4.26 \%$ in female) in contrast to this study. Since these studies were conducted on different ethnic populations (South Indian, Italian and Turkish people, respectively) wide range of findings reminded us genetic factors might be responsible. In the studies that have analyzed the anatomical features of IOF in Turkish population reported by Kazkayasi et al (17). and Canan et al (20)., the prevalence of double IOF was reported as $5 \%$ and $11.5 \%$, respectively. In this study, prevalence of double IOF was found as $12 \%$, and this value was considered to be in the range provided by the worldwide literature. We believe that the studies with larger series in various ethnical populations and meta-analysis of literature would be helpful to clarify the issue.

Absence of cadaveric correlation of CT findings is the limitation of our study. But previous comparative studies have already shown that CT could be used as a reliable technique in the planning of mid-face, orbital and dental surgery.

The current study has revealed the detailed anatomy of IOC and related anatomical structures. In the patients who will undergo orbital, maxillofacial, or dental surgery, it is important to know detailed anatomy of IOC to protect neurovascular structures within. CT can provide accurate and reliable guidance regarding this issue, correlation with anatomical studies would strengthen the imaging findings. 


\section{REFERENCES}

1. $\mathrm{Xu} \mathrm{H}$, Guo Y, Lv D, et al. Morphological structure of the infraorbital canal using three-dimensional reconstruction. J Craniofac Surg 2012;23:1166-1168

2. Hwang K, Suh MS, Chung IH. Cutaneous distribution of infraorbital nerve. J Craniofac Surg 2004;15:3-5.

3. Moore K, Dalley A. Clinically oriented anatomy. 4th ed. Philadelphia: Lippincott Williams \& Wilkins; 1999:903-905.

4. Traxler H, Windisch A, Geyerhofer U, et al. Arterial blood supply of the maxillary sinus. Clin Anat 1999;12:417-421.

5. Solar P, Geyerhofer U, Traxler H, et al. Blood supply to the maxillary sinus relevant to sinus floor elevation procedures. Clin Oral Implants Res 1999;10:34-44.

6. Drake R, Vogl A, Mitchell A. Gray's Anatomy for Students. Philadelphia: Churchill Livingstone; 2010:933-942.

7. Song WC, Kim JN, Yoo JY, et al. Microanatomy of the infraorbital canal and its connecting canals in the maxilla using 3D reconstruction of microcomputed tomographic images. J Craniofac Surg 2012;23:1184-1187.

8. Raschke R, Hazani R, Yaremchuk MJ. Identifying a safe zone for midface augmentation using anatomic landmarks for the infraorbital foramen. Aesthet Surg 2013;33:13-18.

9. Ella B, Sedarat C, Noble Rda C, et al. Vascular connections of the lateral wall of the sinus: surgical effect in sinus augmentation. Int J Oral Maxillofac Implants 2008;23:1047-1052.

10. Rosano G, Taschieri S, Gaudy JF, et al. Maxillary sinus vascular anatomy and its relation to sinus lift surgery. Clin Oral Implants Res 2011;22:711-715.

11. Hindy AM, Abdel-Raouf F. A study of infraorbital foramen, canal and nerve in adult Egyptians. Egypt Dent J 1993;39:573-580.

12. Lee $T$, Lee $H$, Baek S. A threedimensional computed tomographic measurement of the location of infraorbital foramen in East Asians. J Craniofac Surg 2012;23:1169-1173.

13. Lee UY, Nam SH, Han SH, et al. Morphological characteristics of the infraorbital foramen and infraorbital canal using three-dimensional models. Surg Radiol Anat 2006;28:115-120.

14. Apinhasmit W, Chompoopong S, Methathrathip D, et al. .Supraorbital Notch/ Foramen, Infraorbital Foramen and Mental Foramen in Thais:anthropometric me- asurements and surgical relevance. J Med Assoc Thai 2006;89:675-682.

15. Boopathi S, Chakravarthy Marx S, Dhalapathy SL, et al. Anthropometric analysis of the infraorbital foramen in a South Indian population. Singapore Med J 2010;51:730-735.

16. Bressan C, Geuna S, Malerba G, et al Descriptive and topographic anatomy of the accessory infraorbital foramen. Clinical implications in maxillary surgery. Minerva Stomatol 2004;53:495-505.

17. Kazkayasi M, Ergin A, Ersoy M, et al. Microscopic anatomy of the infraorbital canal, nerve, and foramen. Otolaryngol Head Neck Surg 2003;129:692-697.

18. Leo JT, Cassell MD, Bergman RA. Variation in human infraorbital nerve, canal and foramen. Ann Anat 1995;177:93-95.

19. Sato I, Kawai T, Yoshida S, et al. Observing the bony canal structure of the human maxillary sinus in Japanese cadavers using cone beam CT. Okajimas Folia Anat Jpn 2010;87:123-128.

20. Canan S, Asim OM, Okan B, et al. Anatomic variations of the infraorbital foramen. Ann Plast Surg 1999;43:613-617. 
